\title{
ANALISIS KEMAMPUAN BERPIKIR KRITIS MATEMATIKA SISWA PADA MASA PANDEMI COVID-19
}

\author{
Oleh: \\ Tumeal Duri' ${ }^{1}$, Roslian Lubis ${ }^{2}$, Marzuki Ahmad ${ }^{3}$ \\ Fakultas MIPA, Institut Pendidikan Tapanuli Selatan
}

\begin{abstract}
Abstrak
Tujuan penelitian ini adalah untuk mengetahui kemampuan berpikir kritis matematis siswa pada materi hitung garis dan barisan aritmatika di SMA Negeri 1 Padang Bolak. Pendekatan penelitian menggunakan deskriptif kualitatif dan teknik analisis data meliputi reduksi data, penyajian data, dan penarikan kesimpulan. Instrumen penelitian menggunakan tes dan wawancara semiterstruktur. Hasil penelitian menunjukkan rata-rata kemampuan berpikir kritis matematis siswa pada materi hitung garis dan barisan aritmatika di SMA Negeri 1 Padang Bolak adalah 67,26 (kategori cukup). Hanya 8 dari 10 siswa yang mampu menjawab tiga soal dengan lengkap dan sisanya mampu menjawab satu dari tiga soal.
\end{abstract}

Kata kunci: Kemampuan Berpikir Kritis, Pandemi covid-19, Hitung Garis dan Barisan Aritmatika

\begin{abstract}
The aim of study is to know the students' mathematics critical thinking ability on the topic of lines and sequences arithmetic in pandemic Covid-19 period at SMA Negeri 1Padang Bolak. The approach of the research used qualitative descriptive and data analysis technique includes data reduction, data presentation, and taking conclusion. Instrument of the research used test and semistructure interview. the result of the research shows the average of students' mathematics critical thinking ability on the topic of lines and sequences arithmetic in SMA Negeri 1 Padang Bolak is 67.26 (enough category). Only 8 from 10 students are able to answer three question completely and the rest are able to answer one from three questions.
\end{abstract}

Keywords: critical thinking ability, pandemic Covid-19 period at, lines and sequences

\section{PENDAHULUAN}

Pendidikan adalah suatu pondasi dalam hidup yang harus dibangun dengan sebaik mungkin. Pendidikan memegang peranan penting dalam pembangunan bangsa, suatu negara dikatakan berkembang apabila pendidikannya berkembang dan berkualitas. Oleh karena itu, pemerintah harus berupaya untuk meningkatkan mutu pendidikan sehingga dapat menghasilkan Sumber Daya Manusia (SDM) yang bermutu untuk pembangunan bangsa. Pendidikan bertujuan untuk menumbuhkan potensi manusia agar menjadi manusia yang berakal, beradab, dan normal agar menjadi manusia yang beriman dan bertakwa kepada Tuhan Yang Maha Esa (YME), berakhlak mulia, berilmu, kreatif, mandiri, dan menjadi warga negara yang demokratis serta bertanggungjawab.

Pembelajaran matematika dalam kemampuan berpikir kritis merupakan kemampuan yang menggunakan logika. Selain itu, berpikir kritis juga merupakan kemampuan untuk berpikir secara rasional tentang apa yang harus dilakukan. Oleh karena itu, untuk mengetahui kemampuan berpikir kritis matematika perlu dikembangkan keterampilan memahami masalah, membuat model matematika dan menyelesaikan masalah.

Menurut Mahmuzah (2015:64) mengatakan bahwa "Kemampuan berpikir kritis merupakan salah satu aspek penting yang yang sangat diperlukan siswa dalam proses pembelajaran matematika terutama untuk membantu siswa menyelesaikan masalah-masalah matematika yang sulit. Hal ini dikarenakan penggunaan kemampuan berpikir kritis yang tepat akan sangat membantu siswa dalam meningkatkan kemampuan pemecahan masalah.

Email: tumealharahap123@gmail.com 
Adanya pandemi Covid-19 melanda seluruh negeri dibelahan dunia termasuk negara indonesia. Virus corona mewabah di indonesia sejak awal maret 2020. berbagai kebijakan telah dikeluarkan oleh pemerintah Negara Indonesia untuk menerapkan Himbauan kepada masyarakat agar melakukan physical distancing yaitu Himbauan untuk menjaga jarak diantara masyarakat, memakai Masker, menjauhi aktivitas segala bentuk kerumunan, perkumpulan serta menghindari adanya pertemuan yang melibatkan banyak orang(Apriadi et al., 2021). Kebijakan tersebut ditujukan kepada masyarakat agar dapat dilakukan untuk memutus rantai penyebaran Virus corona yang terjadi saat ini.

Berdasarkan hasil wawancara yang dilakukan pada tanggal 30 Januari 2021 dengan guru bidang studi Matematika di kelas XI MIA-4 SMA Negeri 1 Padang Bolak menyatakan bahwa kemampuan berpikir kritis siswa mengalami penurunan. Kemampuan berpikir kritis siswa pada saat proses pembelajaran daring juga kurang optimal dikarenakan tidak belajar secara langsung (daring). (ibu Masridah Harahap, S.Pd., 31 Januari 2012). Sementara itu wawancara dengan beberapa siswa SMA 1 Padang Bolak menyatakan bahwa matematika merupakan pelajaran yang tidak disukai karena pelajaran matematika adalah pelajaran yang sulit dan membosankan karena penuh dengan angka dan hitungan. Jika ada tugas yang paling perlu adalah jawaban bukan proses dalam menjawab.

\section{METODOLOGI PENELITIAN}

Metode penelitian yang digunakan peneliti adalah metode penelitian kualitatif. Sebuah penelitian kualitatif terdapat objek penelitian dan informan penelitian. Adapun yang menjadi objek penelitian ini adalah kemampuan berpikir kritis matematika siswa pada masa pandemi Covid-19. Serta informan penelitian ini adalah guru Matematika di SMA Negeri 1 Padang Bolak, serta beberapa siswa kelas XI MIA-4. Sedangkan sumber data primer dalam penelitian ini adalah siswa kelas XI MIA-4 SMA Negeri 1 Padang Bolak. Sumber data sekunder dalam penelitian ini adalah guru matematika kelas XI MIA-4 SMA Negeri 1 Padang Bolak.

Teknik pengumpulan data penelitian ini dengan menggunakan wawancara dan tes. Wawancara yang digunakan adalah wawancara semiterstruktur (semistructure interview) agar pembahasan lebih terfokus dan mendalam. Wawancara ini menggunakan rekaman suara (audio) agar memudahkan peneliti. Adapun kisi-kisi instrumen kemampuan berpikir kritis matematika siswa dapat dilihat pada tabel berikut:

Tabel 1. Kisi-Kisi Indikator Kemampuan Berpikir Kritis Matematika Siswa

\begin{tabular}{cccc}
\hline No & Indikator & Item Pertanyaan & $\begin{array}{c}\text { Banyak } \\
\text { Pertanyaan }\end{array}$ \\
\hline 1 & Interpretasi & & \\
\hline 2 & Analisis & $1,2,3,4$ & \\
\hline 3 & Evaluasi & & $\mathbf{4}$ \\
\hline 4 & Inferensi & & \\
\hline & Jumlah & & \\
\hline
\end{tabular}

Berdasarkan hasil tes yang dikerjakan oleh siswa, setiap indikator diberi skor. Setelah diperoleh skor tes kemampuan berpikir kritis matematika siswa, peneliti menentukan kategori skor yang diperoleh siswa. Kriteria kemampuan berpikir kritis matematika siswa berdasarkan skor dapat dilihat pada tabel berikut:

Tabel 2. Kriteria Penilaian Hasil Tes

\begin{tabular}{ccc}
\hline No & Interval & Keterangan \\
\hline 1 & $80-100$ & Tinggi \\
\hline 2 & $50-79$ & Sedang \\
\hline 3 & $0-49$ & Rendah \\
\hline
\end{tabular}

Sumber: Danar (Sihotang, 2016)

Keabsahan Data dilakukan untuk membuktikan apakah penelitian yang dilakukan benarbenar merupakan penelitian ilmiah sekaligus untuk menguji data yang dipereleh. Uji keabsahan data pada penelitian kualitatif dengan menggunakan triangulasi akan lebih meningkatkan kekuatan 
JURNAL MathEdu (Mathematic Education Journal) http://journal.ipts.ac.id/index.php/MathEdu Vol. 4 No. 3 November 2021

data apabila dibandingkan dengan satu pendekatan. Dalam penelitian ini, peneliti menggunakan teknik keabsahan data dengan triangulasi teknik. Triangulasi teknik yaitu peneliti menggunakan teknik pengumpulan data yang berbeda-beda untuk mendapatkan data dari sumber yang sama.

Analisis data dalam penelitian ini menggunakan model Miles dan Huberman. Menurut Miles dan Huberman dalam Silalahi (2012:339) mengatakan "kegiatan analisis terdiri dari tiga alur kegiatan secara bersamaan, yaitu reduksi data, penyajian data, dan penarikan kesimpulan/verifikasi”.

1. Reduksi Data

Reduksi Data adalah merangkum, memilih data-data yang penting dan membuang data yang tidak perlu sehingga data tersebut dapat menghasilkan informasi. Dengan demikian data yang direduksi akan memberikan gambaran yang jelas, dan mempermudah peneliti untuk melakukan pengumpulan data selanjutnya.

2. Penyajian Data

Setelah data direduksi langkah selanjutnya adalah penyajian data. Penyajian Data adalah suatu kegiatan penelitian yang dilakukan untuk mencari informasi dan menarik kesimpulan. Dalam penyajian data dapat dilakukan dengan mengambarkan, menjelaskan, serta menyampaikannya kedalam bentuk narasi maupun dalam presentasi yang dapat dipahami dengan jelas.

3. Kesimpulan/Verifikasi Data

Langkah selanjutnya analisis data kualitatif adalah kesimpulan/Verifikasi data. menarik kesimpulan merupakan analisis lanjutan dari reduksi data dan penyajian data sehingga data dapat disimpulkan dengan bukti-bukti yang kuat dan mendukung serta mempertajam data dan memperjelas pemahaman pada tahap pengumpulan data berikutnya.

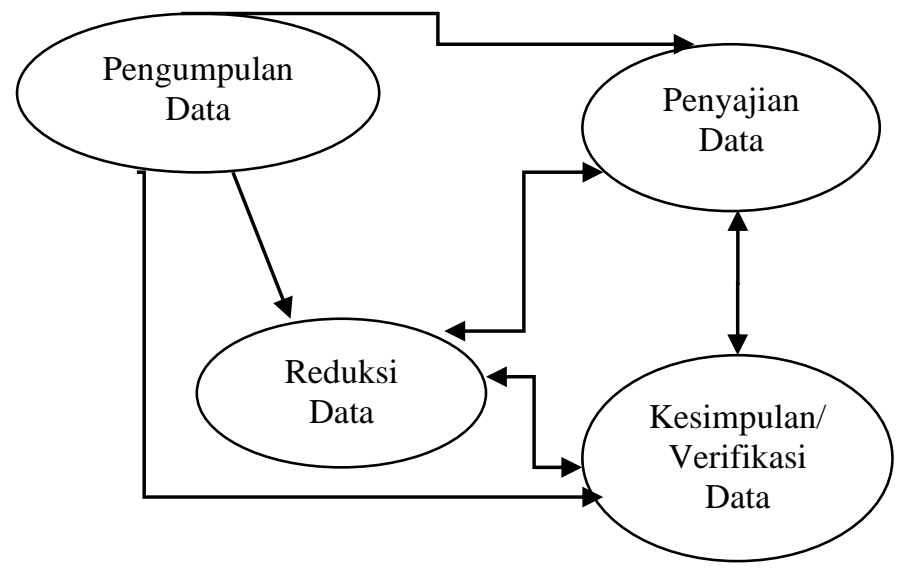

Gambar 1. Komponen Analisis Data

Modifikasi Sugiyono(Ahmad dan Nasution, 2018)

\section{HASIL DAN PEMBAHASAN}

\section{Hasil Penelitian}

Setelah mengadakan penelitian peneliti terkait hasil penelitian yang menggunakan tes. Dengan tes ini dapat diketahui siswa yang tergolong dalam mempunyai kemampuan tinggi, sedang dan rendah. Adapun hasil tes akan dipaparkan sebagai berikut:

Tabel 3. Banyak Soal yang Dijawab Siswa Kelas XI MIA-4 SMA Negeri 1 Padang Bolak

\begin{tabular}{clccc}
\hline No. & Inisial Subjek & $\begin{array}{c}\text { Jenis } \\
\text { Kelamin }\end{array}$ & $\begin{array}{c}\text { Jumlah yang } \\
\text { dijawab }\end{array}$ & Nilai \\
\hline 1 & AH & $\mathrm{P}$ & 3 & 100 \\
\hline 2 & DYS & $\mathrm{P}$ & 3 & 87,5 \\
\hline 3 & DTS & $\mathrm{P}$ & 3 & 100 \\
\hline
\end{tabular}


JURNAL MathEdu (Mathematic Education Journal) http://journal.ipts.ac.id/index.php/MathEdu

\begin{tabular}{clllc}
\hline 4 & FH & P & 3 & 100 \\
\hline 5 & NH & P & 3 & 64,5 \\
\hline 6 & MS & P & 1 & 33,3 \\
\hline 7 & MWB & P & 3 & 68,7 \\
\hline 8 & RS & P & 3 & 33,3 \\
\hline 9 & SW & P & 1 & 33,3 \\
\hline 10 & SWR & P & 3 & 52 \\
\hline \multicolumn{7}{c}{ Jumlah } & $\mathbf{6 7 2 , 6}$ \\
\hline & Rata-rata & $\mathbf{6 7 , 2 6}$ \\
\hline
\end{tabular}

Berdasarkan tabel 3 diatas, dapat dilihat bahwa kemampuan berpikir kriris matematika siswa di SMA Negeri 1 Padang Bolak kelas XI MIA-4 berada pada kategori sedang yakni dengan rata-rata 67,26. Dimana hanya 8 siswa yang menjawab ketiga soal dari siswa di kelas XI MIA-4 SMA Negeri 1 Padang Bolak, selebihnya hanya mampu menjawab satu soal dari tiga soal yang diberikan peneliti. Sesuai dengan pengambilan subjek diambil 3 siswa untuk dianalisis jawaban soal kemampuan berpikir kritis. pengambilan 3 siswa dilakukan dengan pertimbangan yang berfokus pada tujuan untuk menganalisis kemampuan berpikir kritis dan dengan kesepakatan guru kelas XI MIA-4 dengan peneliti:

Tabel 4. Daftar Nama Subjek Berkemampuan Tinggi, Sedang dan Rendah

\begin{tabular}{|c|c|}
\hline No. & Inisial Subjek \\
\hline 1 & FH \\
\hline 2 & MWB \\
\hline 3 & MS \\
\hline
\end{tabular}

\section{Pembahasan}

Hasil penelitian yang telah dianalisis peneliti mengenai kemampuan berpikir kritis matematika siswa pada materi Barisan dan Deret Aritmatika. Berdasarkan uraian hasil penelitian diatas, untuk mempermudah peneliti dalam melakukan analisis data. Hasil penelitian yang telah dianalisis peneliti ditemukan bahwa siswa memiliki berbagai kemampuan matematika yang berbeda.

Subjek FH yang berkemampuan tinggi, dalam tahap memahami soal sangat baik karena subjek FH menurut guru matematika termasuk rajin belajar dan aktif pada saat pembelajaran. Sejalan dengan menurut Charli (2018:48) menyatakan bahwa "faktor penyebab kesulitan siswa dalam memahami soal yaitu siswa dituntut untuk giat belajar agar pemahaman konsep terhadap materi suhu dan kalor siswa lebih luas dan mendalam, sehingga membuat siswa lebih mudah memahami maksud dan tujuan soal". Menurut Hardiningrum (2018:2.327-2.328) menyatakan bahwa "faktor intrinsik yang mempengaruhi motivasi belajar dikarenakan faktor kemampuan belajar siswa diantaranya keinginan mengetahui lebih dalam terhadap sesuatu yang dipelajari, jika ada soal yang sulit tetap bersungguh-sungguh untuk selesai mengerjakan, dan mengerjakan tugas sampai selesai".

Selanjutnya dari pendapat diatas penulis menyimpulkan bahwa faktor penyebab berkemampuan tinggi dikarenakan rajin belajar atau giat dalam belajar untuk membuat siswa lebih mudah memahami dan mengerjakan tugas. Berdasarkan teori tersebut maka siswa dapat menjelaskan apa yang diketahui, yang ditanyakan, membuat model matematika, membuat strategi dalam menyelesaikan soal, dan membuat kesimpulan. Hal ini menunjukkan bahwa subjek FH memenuhi indikator kemampuan berpikir kritis.

Subjek MWB yang berkemampuan sedang, dalam tahap memahami soal cukup baik karena subjek MWB menurut guru matematika kurang bertanya pada saat pembelajaran. Sejalan dengan menurut Jamal (2014:33) menyatakan bahwa "faktor siswa jarang mengajukan pertanyaan ke guru ketika proses belajar mengajar berlangsung, sebanyak 7 siswa jarang mengajukan pertanyaan dalam belajar matematika". Menurut Putridayani (2020:62) menyatakan bahwa "kurangnya pemahaman siswa dalam memahami konsep peluang, masih terdapat siswa yang dikategorikan masih kurang baik yaitu sebanyak 7 orang siswa, dikarenakan siswa kurangnya memamfaatkan waktu untuk bertanya mengenai materi yang kurang dimengerti, kurangnya rasa percaya diri pada diri siswa, saat ditanya apakah siswa dapat memahami materi yang telah disampaikan". Menurut Ahmad (2016:49) menyatakan bahwa "aktivitas mengajukan pertanyaan diperoleh nilai rata-rata. 
Hal ini karena siswa masih enggan mengajukan pertanyaan, karena kebiasaan guru yang selalu mengajar di depan kelas sementara siswa mendengar apa kata guru”.

Selanjutnya dari beberapa pendapat ahli diatas penulis menyimpulkan bahwa faktor penyebab berkemampuan sedang dikarenakan kurang pemahaman siswa dalam memahami soal, dan kurang bertanya mengenai materi yang kurang dimengerti pada saat pembelajaran. Berdasarkan teori tersebut maka siswa memang dapat menjelaskan apa yang diketahui, yang ditanyakan, dan membuat model matematika. Akan tetapi siswa kurang mampu dalam menyelesaikan soal. Siswa juga dapat membuat kesimpulan. Hal ini menunjukkan bahwa subjek MWB sebagian memenuhi indikator kemampuan berpikir kritis.

Subjek MS yang berkemampuan rendah, dalam tahap memahami soal kurang baik karena Subjek MS menurut guru matematika kurang minat belajar atau tertarik belajar matematika. Sejalan dengan menurut Charli (2018:48) menyatakan bahwa "faktor yang menyebabkan siswa mengalami kesulitan dalam melakukan operasi hitung yaitu siswa kurang tertarik dengan soal yang menggunakan operasi hitung, tidak teliti dalam melakukan perhitungan, merasa rumit dalam menjawab soal hitungan, kesulitan menghitung bilangan berpangkat serta kesulitan menghitung bilangan berkoma. Menurut Jamal (2014:33) menyatakan bahwa "Faktor yang sangat mempengaruhi kesulitan belajar siswa adalah kurangnya minat belajar siswa dalam matematika, dapat dilihat dalam pertanyaan angket nomor 10, dimana siswa banyak menjawab guru hanya mencatat saja di papan tulis, sebanyak 8 siswa menjawab".

Selanjutnya dari pendapat diatas penulis menyimpulkan bahwa faktor penyebab berkemampuan rendah dikarenakan kurang tertarik dalam belajar matematika karena menggunakan angka, rumus yang membuat bosan. Berdasarkan teori tersebut maka siswa memang dapat menjelaskan apa yang diketahui, yang ditanyakan. Akan tetapi dalam menyelesaikan soal dan membuat model matematika kurang mampu. Siswa juga dapat membuat kesimpulan. Hal ini menunjukkan bahwa subjek MS sebagian memenuhi indikator kemampuan berpikir kritis.

\section{KESIMPULAN}

\section{Kesimpulan}

Berdasarkan hasil penelitian dan pembahasan penelitian yang telah diperoleh analisis kemampuan berpikir kritis matematika siswa kelas XI MIA-4 dapat disimpulkan sebagai berikut:

1. Siswa yang memiliki kemampuan tinggi yang dimana Subjek FH berada dalam kategori sangat baik karena mampu memahami soal, membuat model matematika, sehingga subjek juga mampu membuat strategi dalam menyelesaikan soal dengan sangat baik, selain ini subjek juga mampu membuat kesimpulan terhadap penyelesaiannya. Sehingga dapat disimpulkan bahwa subjek FH memenuhi indikator kemampuan berpikir kritis.

2. Siswa yang memiliki kemampuan sedang yang dimana Subjek MWB berada dalam kategori cukup baik karena mampu memahami soal dan membuat model matematika. Akan tetapi strategi dalam menyelesaikan soal kurang mampu, dan mampu membuat kesimpulan. Hal tersebut dapat dilihat dari langkah-langkah subjek dalam menyelesaikan soal. Sehingga dapat disimpulkan bahwa subjek MWB sebagian memenuhi indikator kemampuan berpikir kritis.

3. Siswa yang memiliki kemampuan rendah yang dimana subjek MS berada dalam kategori kurang baik karena subjek MS memang mampu memahami soal. Akan tetapi strategi dalam menyelesaikan soal dan membuat model matematika, membuat kesimpulan dengan kurang baik. Hal tesebut dapat dilihat bahwa subjek MS memang tidak mengerjakan ketiga soal tersebut. Sehingga subjek MS sebagian memenuhi indikator kemampuan berpikir kritis.

\section{Implikasi}

Berdasarkan kesimpulan diatas, maka penelitian ini memberikan implikasi terhadap Analisis Kemampuan Berpikir Kritis Matematika Siswa pada Masa Pandemi Covid-19 merupakan bahwa kemampuan berpikir kritis siswa matematika pasti berbeda antara siswa yang satu dengan yang lainnya. Hal ini juga dapat dilihat dari bagaimana cara siswa dalam menyelesaikan permasalahan atau soal matematika. Seperti setiap siswa yang memiliki kemampuan tinggi pasti akan menghasilkan penyelesaian soal yang baik. Sedangkan siswa dengan kemampuan rendah akan menghasilkan penyelesaian soal yang kurang baik, begitu pula dengan kemampuan berpikir kritis dalam matematika. Kemampuan berpikir kritis siswa dalam menyelesaikan soal matematika dapat ditingkatkan dengan rajin mengerjakan latihan-latihan soal yang berbasis cerita yang membutuhkan analisis serta penalaran yang baik untuk dapat menyelesaikannya. 
JURNAL MathEdu (Mathematic Education Journal) http://journal.ipts.ac.id/index.php/MathEdu Vol. 4 No. 3 November 2021

Saran

Berdasarkan penulisan tersebut maka, dapat menjadi bahan masukan yang bermanfaat bagi pihak-pihak terkait antara lain

1. Sekolah

Tes kemampuan berpikir kritis hendaknya menjadi salah satu tes yang diberikan kepada siswa khususnya siswa di SMA Negeri 1 Padang Bolak, sehingga memudahkan penanganan di dalam pembelajaran selama masa pandemi covid-19.

2. Guru

Guru hendaknya menyusun dan melaksanakan pembelajaran dengan mempertimbangkan jenis kemampuan berpikir kritis siswa selama masa pandemi covid-19. Karena yang berbeda mengakibatkan perbedaan pencapaian hasil belajar siswa.

3. Siswa

Siswa hendaknya berusaha untuk sering berlatih dalam mengerjakan soal pemecahan masalah dalam melaksanakan pembelajaran daring. Supaya kemampuan berpikir kritis matematika dapat ditingkatkan.

4. Peneliti selanjutnya

Peneliti selanjutnya hendaknya menggunakan hasil penelitian ini sebagai bahan perbandingan serta lebih detail memberikan perintah dalam lembar soal. Sehingga kendala-kendala yang dihadapi dapat diminimalisisir, temuan positifnya dapat menjadi referensi bagi rancangan penelitian selanjutnya.

5. Pembaca

Pembaca hendaknya dapat menggunakan hasil penelitian sebagai informasi tentang kemampuan berpikir kritis matematika siswa di kelas XI MIA-4 dengan materi pokok Barisan dan Deret Aritmatika.

\section{REFERENSI}

Ahmad, Marzuki dan Nasution, Dwi Putria. 2018. Analisis Kualitatif Kemampuan Komunikasi Matematis Siswa Yang Diberi Pembelajaran Matematika Realistik. Jurnal Gantang. Hal. 83-95.

Ahmad, Marzuki. 2016. Aktivitas Aktif Siswa dalam Pembelajaran Matematika Realistik (PMR). Jurnal Education and development STKIP Tapanuli Selatan. Vol. 2 No. 5. Hal. 45-51.

Apriadi, M. A., Elindra, R., \& Harahap, M. S. (2021). MATEMATIS SISWA SEBELUM DAN SESUDAH MASA PANDEMI COVID-19. Jurnal MathEdu, 4(1), 133-144.

Charli, Leo. 2018. Kesulitan Siswa dalam Menyelesaikan Soal Fisika pada Materi Suhu dan Kalor di Kelas X SMA Ar-Risalah Lubuklinggau Tahun Pelajaran 2016/2017. Journal of Education and Instruction (JOEAI). Volume 1, No. 1. Hal. 42-52.

Harahap, Masridah. 2021. Kemampuan Berpikir Kritis Matematika. Gunungtua. 15 menit.

Hardiningrum, Rikha Setyati. 2018. Faktor-Faktor yang Mempengaruhi Motivasi Belajar Siswa Kelas V SD Negeri Se-kecamatan Ngluwar Kabupaten Magelang. Jurnal Pendidikan Guru SekolahDasar.

Jamal, Fakhrul. 2014. Analisis Kesulitan Belajar Siswa dalam Mata Pelajaran Matematika pada Materi Peluang Kelas XI IPA SMA Muhammadiyah Meulaboh Johan Pahlawan. Jurnal Maju (Jurnal Pendidikan Matematika). Vol. 1, No. 1. Hal. 18-36.

Mahmuzah, Rifaatul. 2015. Peningkatan Kemampuan Berpiki Kritis Matematis Siswa SMP Melalui Pendekatan Problem Possing. Jurnal Peluang. Volume 4, Nomor 1. Hal. 64-72.

Silalahi, Ulber. 2012. Metode Penelitian Sosial. Bandung: Refika Aditama.

Zein, Afrizal. 2020. Pendeteksian Virus Corona dalam Gambar X-Ray Menggunakan Algoritma Artificial Intelligence dengan Deep Learning Python. Jurnal Teknologi Informasi Esit. Vol. XV No. 01. Hal. 19-23. 